\title{
Comparison of the Effects of Heparin 1000 and 5000 Units on Arterial Blood Gases
}

\author{
Reza Borabadi ${ }^{1}$, Mostafa Rad ${ }^{2}$, Mohammad Hassan Rakhshani ${ }^{3}$, Mojtaba Rad ${ }^{4}$ \\ ${ }^{1}$ Department of Nursing, Nursing and Midwifery School, Sabzevar University of Medical Sciences, Sabzevar, Iran \\ 2Department of Nursing, Nursing and Midwifery School, Iranian Research Center on Healthy Aging, Sabzevar \\ University of Medical Sciences, Sabzevar, Iran \\ ${ }^{3}$ Department of Biostatistics and eEpidemiology, School of Health, Iranian Research Center on Healthy Aging, \\ Sabzevar University of Medical Sciences, Sabzevar, Iran \\ ${ }^{4}$ Department of Medical Emergencies, School of Allied Medical Sciences, \\ Sabzevar University of Medical Sciences, Sabzevar, Iran
}

\section{SUMMARY}

Analysis of arterial blood gases is necessary for managing the respiratory and metabolic parameters of patients in the intensive care unit. The aim of this study was to compare the effects of heparin $\mathbf{1 0 0 0}$ and heparin 5000 units on arterial blood gases in patients admitted to the intensive care unit. This study was a triple-blinded clinical trial. A total of 78 patients with head injury were randomly selected from the emergency department of a hospital in an urban area of Iran in 2017. Data was collected using a questionnaire and a checklist of laboratory parameters. Data was analyzed using descriptive and inferential statistical methods via the $\mathrm{R}$ software.

Statistically significant differences in $\mathrm{Na}, \mathrm{SaO} 2, \mathrm{Ca}, \mathrm{BEecf}(\mathrm{p}<0.001)$, and $\mathrm{HCO}, \mathrm{BEe}$ and $\mathrm{K}$ were observed between the two groups $(p<0.01)$. No statistically significant difference between the values of $\mathrm{PaCO} 2, \mathrm{PH}$ and $\mathrm{PaO} 2$ in the two groups were reported $(\mathrm{p}>0.05)$.

The results of this study confirmed that heparin 1000 and heparin 5000 units had no effects on respiratory parameters in analyzing arterial blood gases. However, the concentration of heparin had a significant effect on metabolic parameters for the analysis of arterial blood gases and electrolytes.

Key words: heparin concentration, arterial blood gas, electrolyte

Corresponding author:

Mojtaba Rad

e-mail: Rad.mojtaba89@yahoo.com 


\section{INTRODUCTION}

Analysis of arterial blood gases is recognized as a golden standard in the intensive care unit for the assessment of the respiratory system and the acid and base condition in patients with electrolyte and respiratory disorders (1). Acid and base disorders can lead to life-threatening complications in the disease process. The process of analyzing and monitoring arterial blood gases is an essential part of the diagnosis and treatment processes, oxygenation and the acidbase balance, especially in patients admitted to the intensive care unit. It is required for the diagnosis of acid and base disorders by the physician in patients with respiratory and metabolic problems $(2-4)$. Besides the measurement of gases and electrolytes, arterial blood gas tests can measure methemoglobin, carboxy hemoglobin and hemoglobin levels. This information is essential for the treatment of patients suffering from acid and base disorders and respiratory or metabolic diseases (5). Heparin in the form of liquid is used as anticoagulant in the blood gases test, which may influence the results of these parameters $(6,7)$. The minimum amount of blood needed for analyzing arterial blood gases is $0.3 \mathrm{ml}$. A high proportion of heparin to the blood volume can lead to an increase in the final concentration of heparin and blood dilution, which may be a major contributor to medical errors in patients admitted to the intensive care unit. This is very important in neonates as collecting blood samples is difficult (8). Sampling from the arterial line, which is continuously heparinized by the catheter route is one of the most common laboratory errors in sampling arterial blood gases (9). Hamilton et al. illustrated that the effect of heparin on blood parameters was $35-50 \%$. The results of this study emphasized that the level of heparin affected $\mathrm{PaO} 2$ and $\mathrm{PaCO} 2 \mathrm{pH}$ with the highest effect on $\mathrm{PaCO} 2$. Sachs et al. also showed that in the presence of dif-ferent concentrations of heparin and calcium levels also decreased by $5 \%$ (4). This evidence suggests that heparin affects not only blood gases but also influ-ences electrolytes including calcium, potassium, sodi-um, chlorine, etc.

In a study by Chhapola et al. the effect of different heparin volumes on arterial blood gases and electrolyte parameters, increased heparin levels reduced $\mathrm{PaCO} 2, \mathrm{Na}$ and $\mathrm{HCO} 3$ was investigated, but it had no statistically significant effect on $\mathrm{PaO} 2$ levels (10).
Sampling for appropriate examinations is one of the tasks of a medical team. Most laboratory errors are related to the pre-analysis steps and the wrong technique performed by healthcare staff. Also, the collection of a sample with a heparin-impregnated syringe with different concentrations is one of the sources of errors before analysis. The attention of the healthcare staff to the details of the patient's readiness for sampling, sampling process, and sending it to the laboratory influence the accuracy of results (11). An incorrect use of heparin to impregnate the syringe may increase the acidity level in arterial blood gases, which may disturb the diagnosis and treatment of patients (1). Despite its importance, the correct amount of heparin concentration and the amount of blood sample required to prevent the negative effect of heparin concentration on arterial blood gases have not been reported. Therefore, there are various hospital policies for blood sampling (1). Different sampling by nurses in various nursing wards for impregnating the syringe in terms of the amount of heparin can lead to a lack of unity for performing the procedure and policy in treatment centers. Therefore, the aim of this study was to compare the difference between heparin 1000 and heparin 5000 units on arterial blood gases, which could lead to the recommendation of a united procedure for performing this test.

\section{METHODS}

This randomized, triple-blinded clinical trial was performed in a hospital in an urban area of Iran in 2017. In this study, the sample collector, laboratory expert, and data analyst were blinded to the study. It was performed on 78 patients with a traumatic head injury with GCS $=5-8$ who underwent mechanical ventilation support and were hospitalized in the intensive care unit in an urban area of Iran. Blood sampling was conducted after obtaining the required permissions, providing explanations about the method and aim of the study and signing the informed consent form by the legal guardian of the patients.

Inclusion criteria were: the patients' willingness to participate in the study, appropriate arterial blood flow to the limb for blood sampling, aged 18 - 70 years, traumatic head injury and receiving mechanical ventilation support for one week, mechanical ventilation support for at least 15 min- 
utes before blood sampling, level of consciousness of 5 - 8 based on the Glasgow Coma Scale, and the hemoglobin level $>10$.

Exclusion criteria were: the presence of a lesion or fistula on the limb, evidence of peripheral vascular diseases around the site of blood sampling, any coagulopathy or moderate to high doses of anticoagulant therapy, the presence of active infection in the arterial line and any damage to the limb including fractures, dislocation, burns, acute chest traumas and underlying diseases such as heart, kidney and lung diseases, and diabetes that could affect the results of arterial blood gases.

Therefore, 156 sample were selected of which 78 eligible patients were recruited in this study. A randomized sampling method was used, so that heparinized syringes were randomly selected using flipping the coin. Codes $\mathrm{A}$ and $\mathrm{B}$ were given to the syringes and were defined as A1, A2, A3...A78 and B1, B2, B3...B78. The samples were assigned into the heparin groups of 1000 units (syringes with heparin 1000 units) and heparin group 5000 units (the common method of heparin administration using syringes with heparin 5000 units). To maintain the same conditions in the groups, two specimens of the same patient in terms of all possible confounding factors and homogeneity were taken. Therefore, $1 \mathrm{ml}$ blood was taken using insulin syringes of heparin 1000 units and heparin 5000 units from the radial artery of each patient, coded as A and B (for controlling time as a confounding factor), placed in an ice cube and sent to the laboratory within $10 \mathrm{~min}$ utes. Laboratory staff who had no information of the sampling process analyzed them using the Medica Easy Stat analyzer ${ }^{\circledR}$ made by the USA in 2016. Before the study, this device was calibrated and tested using three standard solutions of alkalosis, acidosis and normal acidity every 24 hours automatically (in 8 minutes) in the first morning shift and manually at the end of the morning shift. In case of any problem, the company's representative was requested to resolve the problem. The accuracy (reliability) of insulin syringes was assessed using 10 syringes as they were filled and emptied, and different volumes and amounts of the remaining heparin in the dead space of the needle and syringe were assessed. It should be noted that the analysis time from each sample to the next sample was two minutes. Data were recorded in the checklist of arterial blood gases for each patient and a checklist of the results of laboratory parame- ters. For the validity of the questionnaire and checklist, 10 faculty members of the school of nursing assessed qualitative content validity, which led to some modifications.

\section{Ethical considerations}

Each questionnaire was coded to ensure the anonymity of the patients. The ethics code (IR.MEDSAB.REC.1396.62) for this research was granted by the ethics committee affiliated with Sabzevar University of Medical Sciences. This study was registered on the Iranian clinical trials registration website with the following decree code: IRCT2017091836266N1.

The collected data was entered into the software $\mathrm{R}$ and descriptive and inferential statistics were used for data analysis. The mean and frequency were used to determine the distribution of variables. Also, paired t-test and Wilcoxon test were used for the analysis of data with normal and non-normal distributions, respectively. The significant level was considered $\mathrm{p}<0.05$.

\section{RESULTS}

The participants included 51 male (65\%) and 27 female $(33.8 \%)$ patients aged $18-65$ years, with a mean age $37.76 \pm 13.42$ years. The patients were diagnosed with intracranial hemorrhage $(17 \%)$, subdural hemor-

Table 1. Arterial blood gases and electrolytes in the groups

\begin{tabular}{|c|c|c|c|}
\hline Variables & Groups & & P-value \\
\hline & $\begin{array}{c}\text { Heparin } 5000 \\
\text { units } \\
\text { Mean } \pm \text { SD }\end{array}$ & $\begin{array}{l}\text { Heparin } 1000 \\
\text { units } \\
\text { Mean } \pm \mathrm{SD}^{* * *}\end{array}$ & \\
\hline $\mathrm{pH}$ & $7.43 \pm 0.06$ & $7.44 \pm 0.07$ & 0.464 \\
\hline $\mathrm{HCO} 3$ & $25.94 \pm 0.43$ & $26.12 \pm 0.45$ & $0.003^{*}$ \\
\hline $\mathrm{PaCO} 2$ & $37.73 \pm 0.75$ & $37.91 \pm 0.82$ & 0.597 \\
\hline $\mathrm{PaO} 2$ & $92.85 \pm 0.83$ & $92.57 \pm 0.81$ & 0.766 \\
\hline Bee & $1.99 \pm 0.45$ & $1.86 \pm 0.46$ & $0.002^{*}$ \\
\hline BEecf & $2.02 \pm 0.40$ & $1.89 \pm 0.41$ & $<0.001^{* *}$ \\
\hline $\mathrm{SaO} 2$ & $97.85 \pm 0.19$ & $97.79 \pm 0.18$ & $<0.001^{* *}$ \\
\hline $\mathrm{Ca}$ & $1.13 \pm 0.04$ & $1.03 \pm 0.05$ & $<0.001^{* *}$ \\
\hline $\mathrm{Na}$ & $135.65 \pm 0.070$ & $137.49 \pm 0.61$ & $<0.001^{* *}$ \\
\hline $\mathrm{K}$ & $3.97 \pm 0.08$ & $3.93 \pm 0.010$ & $0.001^{* *}$ \\
\hline
\end{tabular}

${ }^{*} \mathrm{P}<0.01 ;{ }^{* *} \mathrm{P}<0.001 ;{ }^{* *}$ Standard Deviation 
rhage $(34 \%)$, sub arachnoid hemorrhage (25.5\%), epidural hemorrhage $(13.5 \%)$ and diffused axonal injury $(10 \%)$. The mean values of $\mathrm{pH}, \mathrm{PaO} 2$, and $\mathrm{Na}$ in the group of heparin 1000 units were higher than those of heparin 5000 units. The mean variables of $\mathrm{HCO} 3, \mathrm{PaCO} 2, \mathrm{BEe}, \mathrm{BEecf}, \mathrm{SaO} 2, \mathrm{Ca}, \mathrm{K}$ in the heparin group 5000 units were higher than those of heparin 1000 units. No statistically significant differences between the values of $\mathrm{PaCO} 2, \mathrm{pH}$ and $\mathrm{PaO} 2$ in the groups were reported $(p>0.05)$. There were statistically significant differences between $\mathrm{Na}, \mathrm{SaO} 2, \mathrm{Ca}$, BEecf, HCO3 BEe and $\mathrm{K}$ values $(\mathrm{p}<0.01)$. The mean and standard deviation of variables in the groups of heparin 1000 units and heparin 5,000 units were reported in Table 1.

\section{DISCUSSION}

In this study, the difference between heparin 1000 and heparin 5000 units on arterial blood gases were studied, which showed some changes in arterial blood gases and other variables.

There were no significant differences between the results of $\mathrm{pH}, \mathrm{PaO} 2$ and $\mathrm{PaCO} 2$ in the groups $(\mathrm{p}$ $>0.05$ ). Therefore, the results of this study were consis-tent in the $\mathrm{PaO} 2$ parameter with the result of the study by Malekzadeh et al., whereas in $\mathrm{PaCO} 2$ and $\mathrm{pH}$ parameters were converse with the results of studies of Malekzadeh et al., Copula et al., Hooper et al., Zokaei et al $(1,10,12,13)$. It seems that the nonsignificant results of $\mathrm{PaCO} 2$ and $\mathrm{pH}$ parameters in this study could be attributed to the concentration of heparin, because in some studies with significant statistical results, the heparin concentration was 15 $30 \%$ (1). However, in this study according to the suggestion by Hutchison for the prevention of fatal effects of heparin on the results of arterial blood parameters, 20 units per milliliter were used (1). Chhopola considers that the effect of heparin on $\mathrm{pH}$ and $\mathrm{PaO} 2$, with the concentrations of heparin more than $40 \%$ and $35 \%$, has a false effect (10). Hajin and Zokaei believe that the effect of heparin in the concentration of more than $10 \%$ causes a statistically significant change in $\mathrm{PaCO} 2(7,13)$. On the other hand, other factors affecting arterial blood gases and electrolytes are the size of the syringe and needle size (14). Since the size of the syringe used in some studies was $2-5$ milliliters $(10,12,13)$, it seems that this factor could also lead to differences in results (15).

Also, the comparison of the mean of $\mathrm{pH}$ in the groups indicated a decrease in $\mathrm{pH}$ in the group of heparin 5000 units than in the group of heparin 1000 units. This reduction was not statistically significant ( $p>0.05)$, but the same amount of difference could be clinically important, possibly causing misdiagnosis and treatment described by other studies (1).

The results of this study on HCO3-, BEe, BEecf and $\mathrm{SaO} 2$ showed significant differences between the groups $(p<0.05)$, which were similar to the results of the studies performed by Malekzadeh et al., Chhopola et al., Hooper et al., and Zokaee et al. $(1,8,12,13)$. In this study, HCO3 in the group of heparin 5000 units compared to the group of heparin 1000 units had lower values in arterial blood, which could indicate the effect of this parameter on the concentra-tion of heparin. A probable reason could be that the increased heparin concentration leads to acid and base disorders including metabolic acidosis due to the reduction of HCO3. In this study, additional hep-arin levels reduced the HCO3-, BEe, BEecf parame-ters, especially in the group of heparin 5000 units compared to the group of heparin 1000 units. There-fore, with increasing the concentration of heparin in syringes, metabolic acidosis occurs, which according to the results of this study has no association with the disease, and additional heparin leads to meta-bolic acidosis, and misinterpretation of the results.

In the present study, a significant difference between the two groups of heparin 1000 units and 5000 units $(p<0.001)$ was reported in terms of electrolytes $(\mathrm{Na}, \mathrm{K}$ and $\mathrm{Ca})$. According to the results, potassium and calcium in the heparin 5000 group compared to the heparin 1000 group had higher levels in arterial blood gases indicating an increased effect of heparin concentration on calcium and potassium levels. The results of this study were similar to those of studies by Chhopola et al., Hooper et al., Zokaee et al. $(10,12,13)$ and were converse to the results of studies by Hijin et al. and Hooper et al. in terms of calcium levels $(7,12)$.

Researchers believe that heparin concentrations should not exceed $10 \mathrm{IU} / \mathrm{mL}$ of ionized calcium, which results in disturbances and mistakes in the parameters of arterial blood gases, especially calcium that is more sensitive to heparin concentrations (7).

The results of this study showed a difference in sodium levels in two groups with heparin concentrations of 1000 units and heparin 5,000 units, the sodium levels of which were decreased through increasing the concentration of heparin. This finding can be substantiated by the fact that sodium ion is a 
heparin-soluble salt that is combined with blood. Therefore, increasing the concentration of heparin and sodium increases errors in arterial blood parameters especially electrolytes. The increase in the combined effect of liquid heparin on electrolytes such as $\mathrm{Ca}, \mathrm{Mg}, \mathrm{K}$ in the presence of sodium has been described $(14,16)$. Therefore, with the presence of higher concentrations of heparin, it is expected that sodium levels are reduced and the amounts of other electrolytes such as potassium and calcium are increased, which is also well-documented in terms of clinical significance.

\section{Limitations}

It was impossible to assess arterial blood gases in patients admitted to intensive care units with more health problems. One of the strengths of this study was the large number of samples and similarities of the groups as each patient was considered its own control.

\section{CONCLUSION}

The results of this study indicated that there were no statistically significant differences in $\mathrm{pH}$, $\mathrm{PaO} 2, \mathrm{PaCO} 2$ in the groups of heparin 1000 units and 5000 units indicating that heparin had no effects on respiratory parameters. However, it had significant effects on metabolic parameters such as $\mathrm{HCO}, \mathrm{BE}$, Becf and electrolytes. Therefore, it can be said that heparin used in syringes does not have much effects on respiratory parameters and mainly influence metabolic parameters.

\section{References}

1. Malekzade J. The Effect of Heparin Density in Blood Sampling on the Results of Arterial Blood Gases. J Sabzevar Univ Med Sci 2005; 12(3):14-9. (In Persian)

2. Andrews $\mathrm{T}$, Waterman $\mathrm{H}$. What factors influence arterial blood gas sampling patterns? Nurs Crit Care 2008;13(3):132-7. https://doi.org/10.1111/j.1478-5153.2008.00275.x

3. Hasković E, Bureković A, Husić A, et al. Acid-Base Status of Patients with Diabetic Ketoacidosis and Ketonuria: Bosnia and Herzegovina Experience. Acta Facultatis Medicae Naissensis 2018;35(2):132-9. https://doi.org/10.2478/afmnai-2018-0015
4. Sood P, Paul G, Puri S. Interpretation of arterial blood gas. Indian J Crit Care Med. 2010;14(2):57. https://doi.org/10.4103/0972-5229.68215

5. Dukić L, Milevoj Kopčinović L, Dorotić A, Baršić I. Blood gas testing and related measurements: National recommendations on behalf of the Croatian Society of Medical Biochemistry and Laboratory Medicine. Biochem Med 2016;26(3):318-36. https://doi.org/10.11613/BM.2016.036

6. Pakmehr M, Ghaleno AR. The investigation of heparin effect on arterial blood gases analysis. Med Sci 2018;22(89):65-9. 
7. Higgins C. The use of heparin in preparing samples for blood-gas analysis. MLO Med Labs Obs 2007;39(10):16-8.

8. Chhapola V, Kumar S, Goyal P. Is liquid heparin comparable to dry balanced heparin for blood gas sampling in intensive care unit? Indian J Crit Care Med 2014;18(1):14 -20. https://doi.org/10.4103/0972-5229.125428

9. Bowen RA, Hortin GL, Csako G, et al. Impact of blood collection devices on clinical chemistry assays. Clin Biochem 2010;43(1):4-25. https://doi.org/10.1016/j.clinbiochem.2009.10.001

10. Chhapola V, Kanwal SK, Sharma R, Kumar V. A comparative study on reliability of point of care sodium and potassium estimation in a pediatric intensive care unit. Indian J Pediatr 2013;80(9):731-5. https://doi.org/10.1007/s12098-013-0977-z

11. Lindberg Seemann T, Nybo M. Continuous quality control of the blood sampling procedure using a structured observation scheme. Biochem Med 2016;26(3):337-45. https://doi.org/10.11613/BM.2016.037

12. Hopper K, Rezende ML, Haskins SC. Assessment of the effect of dilution of blood samples with sodium heparin on blood gas, electrolyte, and lactate measurements in dogs. Am J Vet Res 2005;66(4):656-60.

https://doi.org/10.2460/ajvr.2005.66.656

13. Zokaei A, Aghdaei N, Ahmadi SJ. The Effect of Various Amount of Heparin on Analysis of Arterial Blood Gas in Adult Patients Undergoing Open Heart Surgery. Res J Med Sci 2016;10(4):191-3.

14. Küme T, Şişman AR, Solak A, et al.. The effects of different syringe volume, needle size and sample volume on blood gas analysis in syringes washed with heparin. Biochem Med (Zagreb). 2012;22(2):189-201. https://doi.org/10.11613/BM.2012.022

15. Knowles TP, Mullin RA, Hunter JA, Douce HF. Effects of syringe material, sample storage time, and temperature on blood gases and oxygen saturation in arterialized human blood samples. Respiratory Care 2006;51(7):732-6. PMID:16800906

16. Uysal E, Acar YA, Kutur A, Cevik E, Salman N, Tezel O. How reliable are electrolyte and metabolite results measured by a blood gas analyzer in the ED?. Am J Emerg Med 2016;34(3):419-24. https://doi.org/10.1016/j.ajem.2015.11.025 


\title{
Upoređivanje efekata heparina od 1000 jedinica i 5000 jedinica na gasove arterijske krvi
}

\author{
Reza Borabadi ${ }^{1}$, Mostafa Rad ${ }^{2}$, Mohammad Hassan Rakhshani ${ }^{3}$, Mojtaba Rad ${ }^{4}$ \\ ${ }^{1}$ Departman za sestrinstvo, Fakultet za sestrinstvo i akušerstvo, Univerzitet za medicinske naukeu Sabzevaru, \\ Sabzevar, Iran \\ ${ }^{2}$ Departman za sestrinstvo, Fakultet za sestrinstvo i akušerstvo, Iranski istraživački centar za zdravo starenje, \\ Univerzitet za medicinske nauke u Sabzevaru, Sabzevar, Iran \\ ${ }^{3}$ Departman za biostatistiku i epidemiologiju, Fakultet za zdravlje, Iranski istraživački centar za zdravo srarenje, \\ Univerzitet za medicinske nauke u Sabzevaru, Sabzevar, Iran \\ ${ }^{4}$ Departman za urgentnu medicine, Fakultet za udružene medicinske nauke, \\ Univerzitet za medicinske nauke u Sabzevaru, Sabzevar, Iran
}

\section{S A ŽETAK}

Analiza gasova arterijske krvi neophodna je za praćenje respiratornih i metaboličkih parametara kod bolesnika na intenzivnoj nezi. Cilj ove studije bilo je upoređivanje efekata heparina od 1000 jedinica i 5000 jedinica na gasove arterijske krvi kod bolesnika $u$ jedinici intenzivne nege.

Ova studija sprovedena je kao trostruko slepa klinička studija. Izabrano je ukupno 78 bolesnika sa povredama glave metodom slučajnog uzorka, na departmanu urgentne medicine $u$ jednoj od bolnica $u$ urbanom delu Irana, 2017. godine. Podaci su prikupljeni pomoću upitnika i liste laboratorijskih parametara i analizirani su primenom deskriptivnih $i$ inferencijalnih statističkih metoda $\mathbf{u}$ okviru $R$ softvera.

Uočene su statistički značajne razlike u vrednostima $\mathrm{Na}, \mathrm{SaO} 2, \mathrm{Ca}, \mathrm{BEecf}(\mathrm{p}<0,001), \mathrm{HCO}, \mathrm{BEe}$ i K između dveju grupa $(\mathrm{p}<0,01)$. Nije utvrđena statistički značajna razlika među vrednostima $\mathrm{PaCO} 2, \mathrm{PH}$ i $\mathrm{PaO} 2 \mathrm{u}$ krvi ispitanika ovim grupama $(\mathrm{p}>0,05)$.

Rezultati ove studije potvrdili su da heparin od 1000 jedinica i 5000 jedinica nisu imali efekte na respiratorne parametre $u$ analiziranim gasovima arterijske krvi. Međutim, koncentracija heparina imala je značajan uticaj na metaboličke parametre $u$ analizi gasova arterijske krvi i elektrolita.

Ključne reči: koncentracija heparina, gasovi arterijske krvi, elektrolit 